\title{
Pembeda Konsumen Dalam Memilih Tempat Belanja Offline Vs Online
}

\author{
Dede Suleman ${ }^{1}$, Hapzi Ali ${ }^{2}$, Dewi Nusraningrum ${ }^{3}$, \\ Mochammad Mukti Ali ${ }^{4}$ \\ ${ }^{1}$ Universitas Mercubuana Jakarta, dede.dln@bsi.ac.id \\ ${ }^{2}$ Universitas Mercubuana Jakarta, hapzi.ali@mercubuana.ac.id \\ ${ }^{3}$ Universitas Mercubuana Jakarta, dewinusraningrum@mercubuana.ac.id \\ ${ }^{4}$ Universitas Mercubuana Jakarta, mukti.gte@yahoo.com
}

\begin{abstract}
ABSTRAK
Pemasaran era baru menambahkan alternatif tempat belanja bagi konsumen dimana saat ini hadir tempat belanja online dan tempat belanja offline. Sehingga konsumen harus memilih satu pilihan tempat belanja dari kedua alternatif tersebut. Hal ini membuat pemasar perlu memetakan variabel atau faktor apa dari demografis yang membuat konsumen memilih salah satu tempat belanja yang ada. penelitian ini melihat bagaiamana konsumen memutuskan tempat belanja dilihat dari faktor demograsi konsumen. Populasi dari penelitian ini adalah konsumen produk fashion ritel offline dan online, yang mana jumlahnya tidak diketahui pasti sehingga sampel dalam penelitian ini menggunakan non-probabilitas sebanyak 130 responden di DKI Jakarta. Dengan alat analisis SPSS dan alat bantu analisis diskriminan yang digunakan, hasil penelitian ini menunjukkan bahwa faktor pendidikan dan pekerjakan konsumen yang menentukan konsumen memilih belanja di salah satu tempat belanja. Adapun kunci pemasar yang sukses harus fokus untuk menarik konsumen yang tepat denagn cara yang tepat yang sesuai denagn perilaku belanja konsumen.
\end{abstract}

Kata Kunci : Keputusan konsumen, Demografi, Analisis diskriminan

\begin{abstract}
The new era of marketing adds an alternative shopping place for consumers where currently online shopping and offline shopping are present. So consumers must choose a shopping choice of the two alternatives. This makes the marketer need to map out what variables or factors from the demographic that make the consumer choose one of the available shopping places. This study looks at how consumers decide where to shop viewed from the consumer demographic factors. The population of this study is consumers of offline and online retail fashion products, of which the number is unknown, so the sample in this study uses non-probability of 130 respondents in DKI Jakarta. With SPSS analysis tools and discriminant analysis aids used, the results of this study indicate that the factors of education and employing consumers determine consumers to choose shopping at one shopping place. The key to successful marketers must focus on attracting the right consumers with the right way that is appropriate with the consumer's shopping behavior.
\end{abstract}

Keywords: Consumer decisions, Demographics, Discriminant analysis

Naskah diterima: 27-08-2020, direvisi: 01-07-2020, diterbitkan: 01-09-2020 


\section{PENDAHULUAN}

Pada era digital sekarang sangat berbeda dengan sebelumnya(Kotler et al., 2019).Hal ini dapat dilihat dari perkembangan internet yang bertumbuh pesat saat ini di Indonesia (Suleman, 2018). Dalam hal ini tentu memberikan dampak karena konsumen akan mendapatkan berbagai alternative tempat belanja salah satunya tempat belanja online atau retail online (Suleman, Zuniarti, Setyaningsih, et al., 2019). Adanya pilihan tempat belanja ini, akan membuat konsumen memiliki peluang untuk memilih beragam jenis produk dan jasa yang dapat dibelinya. Untuk itu, konsumen cendrung akan memilih sebuah tempat belanja yang memiliki keunggulan (Suleman, Zuniarti, \& Sabil, 2019). Kedua tempat belanja yang hadir ini tentunya menawarkan keunggulan yang berbeda dan juga memiliki ciri khas dan tipe konsumen yang tersendiri yang memilih tempat belanja tersebut (Suleman, Ali, Nusraningrum, et al., 2019). Disinilah terjadi perebutan konsumen antara kedua retail tersebut baik retail offline dan retail online yang perlu di ingat bagi pemasar bahwa konsumen hanya akan memilih salah satu tempat belanja yang memberikan banyak keuntungan baginya (Suleman, Zuniarti, Marginingsih, et al., 2019).

Kondisi pasar saat ini sangatlah beragam hal ini karena terdapat beberapa generasi juga yang menjadi konsumen yang masing-masing generasi memiliki perilaku yang berbeda dimana ada generasi $\mathrm{X}$ dengan rentang usia > 42 tahun, Generasi Y dengan usia 21-41 tahun dan Generasi $Z<21$ tahun (Winasis et al., 2018). Oleh karena itu dengan adanya ragam generasi ditambah dengan ragam tempat belanja menjadikan konsumen akan terbagi. Dimana konsumen pada generasi tertentu pastinya akan memilih belanja di tempat tertentu (Suleman, Ali, et al., 2020). Pemasar harus tahu betul perilaku konsumen masingmasing generasi agar bisa digunakan sebagai acuan dalam pembuatan strategi pemasaran.
Pemasar yang peka dan bisa memahami ini yang akan memenagkan persaingan karena bisa melihat menentukan target dan melakukan segmentasi untuk produk yang dipasarkan sesuai dengan karakteristik produknya. Konsumen yang berbeda ini akan memberikan peluang yang bagus untuk bisa di kelompokan dan disesuiakan dengan perilaku mereka dan juga pilihan tempat belanja mereka (Zuniarti et al., 2020) . Pembeda dalam hal ini bisa dilihat dari demografis konsumen yang mana tentu konsumen yang memiliki perbedaan usia, pekerjaan, pendapatan dan pendidikan ini bisa menggambarkan dan nanti disimpulkan dari factor-faktor tersebut hal mana yang paling membedakan dari tiap konsumen dalam memilih tempat belanja (Suleman, Suharyadi, et al., 2020).

Oleh karena itu dalam penelitian ini peneliti akan memberikan gambaran tentang kondisi ragam konsumen dan pembeda kelompok konsumen dari tiap generasi atas pilihan tempat belanja mereka. Penelitian dari factor demografis konsumen yang ada dari beberapa generasi ini diharapkan hasilnya bisa digunakan gambaran oleh para pemasar untuk melihat konsumen mereka.

\section{KAJIAN LITERATUR}

Penelitian ini bukan merupakan penelitian perbandingan antar variabel antara independen dan dependen. Ini merupakan publikasi bagian dari penelitian besar disertasi yang hanya meneliti tentang bagaimana sebuah keputusan konsumen memilih tempat belanja jika dibandingkan dengan demografis responden yang ada.

Keputusan dapat diartikan sebagai pilihan dari dua tempat atau lebih alternative pilihan yang ada (Schiffman et al., 2010). Dalam hal ini bisa disebutkan bahwa konsumen memilih sebuah tempat belanja antar retail offline dan retail online. Konsumen akan melalui lima tahap dalam pengambilan keputusan pembelian mulai dari pengenalan kebutuhan Merupakan tahap pertama proses keputusan 
pembeli, dimana konsumen menyadari suatu masalah atau kebutuhan. Pencarian informasi Merupakan tahap proses keputusan pembeli dimana konsumen ingin mencari informasi lebih banyak; konsumen mungkin hanya memperbesar perhatian atau melakukan pencarian informasi secara aktif. Evaluasi alternatif Merupakan tahap proses keputusan pembeli dimana konsumen menggunakan informasi untuk mengevaluasi merek alternatif dalam sekelompok pilihan. Keputusan pembelian Merupakan keputusan pembeli tentang merek mana yang paling disukai, tetapi dua faktor bisa berada antara niat pembelian dan keputusan pembelian. Perilaku pasca pembelian Merupakan tahap proses keputusan pembeli dimana konsumen mengambil tindakan selanjutnya setelah pembelian, berdasarkan kepuasan atau ketidakpuasan mereka (Kotler \& Amstrong, 2016).

Dapat dijelaskan bahwa karakteristik dari demografi responden pada umumnya antara lain usia, pendapatan, jenis kelamin dan pekerjaan (Sumawan, 2002) . Pada satu atau dua penelitian hal tersebut bisa berbeda tergantung peneliti. Dikarenakan setiap peneliti memiliki tujuan yang bebeda dalam penelitian nya. Demografis ini juga dapat menjadi petunjuk peneliti terhadap responden untuk menunjukan bahwa setiap individu memiliki perilaku, sikap atau tanggapan yang berbeda- beda terhadap keputusan pembelian terhadap sebuah produk maupun jasa yang ditawarkan pada tempat tertentu. Jenis karakteristik demografi dari seseorang mempengaruhi kerentanan seseorang terhadap berbagai jenis pengaruh sosial terhadap perilaku tertentu (Tulay, 2010) . Jadi berdasarkan dari hasil penelitian tersebut disimpulkan bahwa sebuah variabel demografi (yaitu: jenis kelamin, usia, pendidikan dan pendapatan) sangat berpengaruh terhadap sebuah keputusan untuk memilih sebuah tempat belanja produk fashion. Hal tersebut disebabkan karena setiap demografi seseorang yang berbedabeda memiliki tingkat kebutuhan dan pemahaman akan sebuah produk yang berbedabeda pada setiap individu. Sehingga setiap demografi seseorang secara langsung dapat mempengaruhi respon yang ditunjukkan oleh setiap konsumen. Berdasarkan penjelasan studi sebelumnya, maka terdapat peluang untuk melakukan penelitian lebih lanjut dengan mengintegrasikan variabel demografi dan variabel respon konsumen.

\section{METODE PENELITIAN}

Metode penelitian ini adalah kuantitatif, populasi dalam penelitian ini adalah konsumen yang pernah melakukan pembelian produk fashion di retail offline dan retail online oleh karena itu populasi dalam penelitian jumlah nya besar dan jumlah nya tidak diketahui secara pasti. Sedangkan sampel pada penelitian ini dilakukan dengan non probability sampling dengan kriteria Responden adalah konsumen yang pernah berbelanja produk fashion melalui online ,Responden adalah dengan usia mulai 17 tahun. Responden adalah yang tinggal di sekitar Kota DKI Jakarta. Teknik yang digunakan dalam penelitian ini adalah metode purposive sampling dengan jumlah $\mathrm{n}=130$. Yang akan di olah dengan software sspss 21.

Dengan menggunakan metode analisis yaitu analisis diskriminan yangmerupakan teknik statistika multivariat yang masuk pada metode dependensi (hubungan antar variabel dimana sudah dapat dibedakan variabel respon dan mana variabel penjelas). Analisis diskriminan berusaha untuk mengelompokan setiap objek ke dalam dua atau lebih kelompok berdasarkan pada sejumlah kriteria variabel independen (yamin, sofyan, kurniawan, 2011) . Bisa di artikan bahwa analisis diskriminan adalah teknik untuk menganalisis data ketika kriteria atau variabel dependen bersifat kategoris dan prediktor atau variabel independen bersifat interval.

Dalam analisis diskirminan signifikansi fungsi diskriman dapat dilihat dari nilai Wilk Lamda atau Chi Square. Angka Wilk's Lamda berkisar 0 - 1. Jika Wilk's Lamda mendekati 0 menunjukkan bahwa rata-rata antar group semakin berbeda, tetapi jika Wilk's Lamda semakin mendekati 1 menunjukkan rata-rata 
antar kelompok mendekati sama. Kemudian jika $\mathrm{F}$ hitung $\leq \mathrm{F}$ tabel menunjukkan tak ada perbedaan rata-rata antar kelompok, jika $F$ hitung $>\mathrm{F}$ tabel menunjukkan ada perbedaan rata-rata antar kelompok. Dan Jika Sig. > 0.05 menunjukkan tidak ada perbedaan rata-rata antar kelompok, jika Sig. $\leq 0.05$ menunjukkan ada perbedaan rata-rata antar kelompok. menjamin keakuratan analisis diskriminan semua atribut yang ada tetap disertakan dalam pengolahan data lebih lanjut dengan pengujian hipotesis yang pertama dilakukan dengan uji Khi-Kuadrat pada taraf $\alpha=0,05$ dan dilakukan dengan menggunakan metode stepwise(Wijanto, 2008). Analisis diskriminan berfungsi untuk menemukan besarnya nilai perbedaan antara beberapa kelompok atau kategori yang diukur dari beberapa variabel penentu (diskriminator) juga berfungsi untuk menentukan besarnya peranan tiap diskriminan keputusan pada tiap kategori.

Dalam penelitian ini variabel dependen yang digunakan adalah keputusan berbelanja, untuk responden dikelompokkan menjadi tiga kelompok yaitu retail offline, retail offline dan keduanya, retail offline dengan dummy (0) dan retail online dengan dummy (1) . Keputusan konsumen berbelanja (DTS) diukur dengan menggunakan skala likert dengan jumlah pertanyaan dalam kuesioner sebanyak 5 item indikator.

\section{PEMBAHASAN}

Dalam penelitian ini didapat beberapa hasil penelitian yang telah dilakukan dengan alat analisis dikriminan sebagai berikut dan sebelumnya bisa dilihat demografi dari respoden pada penelitian ini.
Tabel 1

Tests of Equality of Group Means

\begin{tabular}{|l|r|r|r|r|r|}
\multicolumn{7}{|c|}{ Tests of Equality of Group Means } \\
\hline $\begin{array}{l}\text { Wilks' } \\
\text { Lambda }\end{array}$ & \multicolumn{1}{c|}{$\mathrm{F}$} & df1 & df2 & Sig. \\
\hline Usia & .889 & 16.010 & 1 & 128 & .000 \\
Jenis_Kelamin & .996 & .507 & 1 & 128 & .478 \\
Pendidikan & .836 & 25.126 & 1 & 128 & .000 \\
Pekerjaan & .847 & 23.154 & 1 & 128 & .000 \\
Penghasilan & .885 & 16.565 & 1 & 128 & .000 \\
Frekuensi belanja & .964 & 4.819 & 1 & 128 & .030 \\
\hline
\end{tabular}

Sumber: data diolah (2020)

Data Tabel 1 diatas menunjukan hasil, dengan menggunakan uji $F$ pada taraf kesalahan 5\%, variabel usia, pendidikan, pekerjaan, penghasilan berbeda dan frekunsi beli rata-ratanya secara signifikan antara konsumen retail offline dan retail online. Sedangkan variabel jenis kelamin dan frekuensi pembelian tidak terdapat perbedaan yang signifikan antara pilihan kelompok retail offline, retail online dan yang memilih di keduanya

Tabel 2

Classification Function Coefficients

\begin{tabular}{|l|r|r|}
\hline \multirow{2}{*}{} & \multicolumn{2}{|c|}{ Pilihan Belanja } \\
\cline { 2 - 3 } & \multicolumn{1}{|c|}{$\begin{array}{l}\text { Retail } \\
\text { offline }\end{array}$} & $\begin{array}{c}\text { Retail } \\
\text { online }\end{array}$ \\
\hline Pendidikan & 4.999 & 4.336 \\
Pekerjaan & 4.738 & 5.386 \\
Frekuensi belanja & .897 & .391 \\
(Constant) & -7.506 & -7.737 \\
\hline
\end{tabular}

Fisher's linear discriminant functions

Sumber: data diolah (2020)

Pada Tabel 2 diatas yang ditunjukan pada koefisien persamaan diskriminan untuk golongan pelanggan yang berbelanja di retail offline dan retail online. Dapat di artikan tanpa adanya perbedaan pendidikan dan pekerjaan konsumen. Dapat diartikan bahwa 
maka keputusan konsumen berbelanja retail offline adalah negatif 7.506. Dengan adanya kenaikan tingkat pendidikan konsumen sebesar satu satuan maka keputusan konsumen berbelanja di retail offline akan meningkat sebesar 4.999 satuan dan selanjutnya dengan adanya perbedaan tingkat pekerjaan konsumen sebesar satu satuan maka keputusan konsumen berbelanja di retail offline akan meningkat sebesar 4.738 satuan. Dan untuk retail online di artikan tanpa adanya perbedaan pendidikan dan pendapatan konsumen, maka keputusan konsumen berbelanja online adalah negatif 7.737. Dengan adanya kenaikan tingkat pendidikan konsumen sebesar satu satuan maka keputusan konsumen berbelanja di retail online akan meningkat sebesar 4.336 satuan dan selanjutnya dengan adanya kenaikan tingkat pendidikan konsumen sebesar satu satuan maka keputusan konsumen berbelanja di retail online akan meningkat sebesar 5.386 satuan.

\section{PENUTUP}

Dalam penelitian ini dapat disimpulkan bahwa keputusan memilih tempat berbelanja produk fashion sangat dipengaruhi oleh usia,pendidikan,pekerjaan dan penghasilan jika ditarik arti dari output tersebut adalah faktor-faktor ini disebabkan oleh bagaimana suatu kelompok konsumen yang telah terbiasa melakukan pembelian di retail offline sesuai dengan era mereka saat generasi $\mathrm{X}$ dan sebagian lagi dari generasi millennial $\mathrm{Y}$. Sehingga hadirnya alternative tempat belanja retail online masih menjadi hal baru dan perlu adaptasi dalam penggunaannya. Juga dapat dilihat untuk generasi $\mathrm{Z}$ yang memang kurang suka berkomunikasi secara langsung maka akan memilih berbelanja pada retail online. Dan mengenai yang memilih kedua retail tersebut ini juga gambaran dari sebagian generasi $\mathrm{X}$ dan generasi millennial $(\mathrm{Y})$ yang mau mencoba hal baru namun belum sepenuhnya bisa meninggalkan cara berbelanja lama mereka di retail offline.

Terlihat ada dua variabel yaitu pendapatan dan pendidikan, dengan demikian berarti keputusan melakukan pembelian melalui retail online dan retail offline, dipengaruhi oleh karakteristik responden dalam hal pendidikan dan pekerjaan. bahwa semakin tinggi tingkat pendidikan bisa merupakan perwakilan dari tingkatan generasi, semakin tinggi tingkat pekerjaan saat ini berarti masuk kategori generasi $\mathrm{X}$ atau millennial yang masih kurang beradaptasi dengan hadirnya tempat belanja baru sehingga dan masih menggunakan metode belanja lama mereka yang sudah dipercaya dalam proses transaksinya.

Responden dengan penghasilan diatas UMR kota Jakarta pada umumnya sudah memiliki usia dewasa dan masuk pada generasi millennial dan generasi $X$, yang mempunyai cara lama untuk berbelanja produk fashion mereka yaitu di toko offline dan hanya sebagian yang beralih ke toko online namun tidak sepenuhnya menjatuhkan pilihan berbelanja pada toko online meraka masih juga membandingkan dengan toko offline Karena beberapa pertimbangan tersendiri.

Jadi bisa disimpulkan dalam penelitian ini bahwa keputusan konsumen memilih tempat berbelanja ternyata dipengaruhi oleh faktor karakteristik konsumen yaitu pendidikan dan pekerjaan. Bisa di indikasikan bahwa kedua faktor tersebut dipengaruhi ada karena faktor perbedaan generasi. Dalam penelitian pengambilan sampel dari perbedaan kelompok responden akan membuat hasil penelitian, karena masing-masing kelompok punya pilihan tempat dan pola belanja yang berbeda. 


\section{REFERENSI}

Kotler, P., \& Amstrong, gary. (2016). Prinsip-prinsip Pemasaran. Edisil3. Jilid 1. Erlangga.

Kotler, P., Kartajaya, H., \& Setiawan, I. (2019). Marketing 4.0: Moving From Traditional To Digital. In Gramedia. PT. Gramedia Pustaka Utama. https://doi.org/10.1142/9789813275478_ 0004

Schiffman, L., Kanuk, \& Wisenblit, J. (2010). Consumer behavior. 10th edition. Pearson Prentice Hall.

Suleman, D. (2018). Faktor Penentu Keputusan Konsumen Indonesia MemilihTempat Belanja Disebuah ECommerce (Theory of Planned Behavior). Jurnal JDM, I(02), 19http://journal.mercubuana.ac.id/index.p $\mathrm{hp} / \mathrm{jdm} /$ article/view/4120.

Suleman, D., Ali, H., Nusraningrum, D., \& Ali, M. M. (2020). Strategi memenangkan persaingan bisnis berbasis perilaku konsumen untuk produk fashion. Lembaga pendidikan dan pelatihan balai insan cendekia.

Suleman, D., Ali, H., Nusraningrum, D., \& Ali, M. M. A. (2019). Perceived Ease of Use, Trust and Risk toward Attitude and Intention in Shopping for Online Fashion Products In Indonesia. Archives of Business Research, Vol.7(No.4), pp.240-253. https://doi.org/DOI: http://dx.doi.org/10.14738/abr.74.2019

Suleman, D., Suharyadi, D., Rusiyati, S., Sabil, Riftiasari, D., \& Marwansyah, S. (2020). How trust,risk toward attitude when shopping retail online. Dinasti International Journal of Education Management and Social Science, 1(4), Pp :487-492.

https://doi.org/https://doi.org/10.31933/d ijms.v1i4.185

Suleman, D., Zuniarti, I., Marginingsih, R., Sabil, Nurhayaty, E., Rachmawati, S., Pramularso, E. Y., \& Sari, I. (2019). Competition between offline and online stores: when it comes to shopping for fashion products, which store will be the choice of Indonesian consumers? International Conference on Global Innovation and Trends in Economy, 114.

https://easychair.org/publications/preprin $\mathrm{t} / 8 \mathrm{drP}$

Suleman, D., Zuniarti, I., \& Sabil, S. (2019). Consumer Decisions toward Fashion Product Shopping in Indonesia: The effects of Attitude, Perception of Ease of Use, Usefulness, and Trust. Management Dynamics in the Knowledge Economy, $7(2)$, 133-146. https://doi.org/10.25019/mdke/7.2.01

Suleman, D., Zuniarti, I., Setyaningsih, E. D., Yanti, V. A., Susilowati, I. H., Sari, I., Marwansyah, S., Hadi, S. sudarmono, \& Lestiningsih, A. S. (2019). Decision Model Based on Technology Acceptance Model (Tam) for Online Shop Consumers in Indonesia. Academy of Marketing Studies Journal, 23(4), Pp: 114.

https://www.abacademies.org/articles/de cision-model-based-on-technologyacceptance-model-tam-for-online-shopconsumers-in-indonesia-8624.html

Sumawan, U. (2002). Perilaku konsumen: Teori dan Penerapannya dalam Pemasaran. Pt. Ghalia Indonesia dengan MMA-IPB.

Tulay, G. (2010). The Role of Demographics on The Susceptibility to Social Influence: A Pretest Study. Journal of Marketing Development and Competitiveness, 5(1), 9-22.

Wijanto, S. H. (2008). SEM dengan LISREL 8.8. In SEM dengan LISREL 8.8. Graha ilmu.

yamin, sofyan, kurniawan, H. (2011). SPSS COMPLETE,Teknik analisis statistik terlengkap dengan software spss. Salemba infotek.

Zuniarti, I., Suleman, D., Rachmawati, S., Sabil, \& Rusiyati, S. (2020). How Ease of use, usefullness toward attitude of shopping at online retail. Dinasti International Journal of Education Management and Social Science, 1(4), $\mathrm{Pp}: 448-453$.

https://doi.org/https://doi.org/10.31933/d ijemss.v1i4.211 


\section{BIODATA PENULIS}

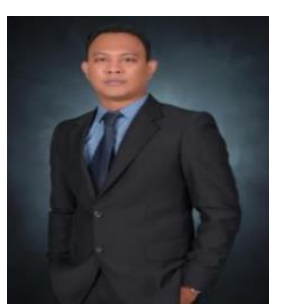

Dr (C)Dede SulemanM.M, Menyelesaikan S1 dari Universitas Azzahra, jurusan Ekonomi, dan gelar Magister Manajemen dari Universitas BSI Bandung dan 2019 ini merupakan kandidat Doktor (c) Manajemen Marketing dari Universitas Mercubuana, Jakarta. Dede Suleman mengawali karier sebagai profesional di bidang ekspor dan import, kemudian sejak 2007 mulai menggeluti usaha di bidang Restaurant saat ini menjabat sebagai Direktur Pemasaran pada Duta Selaras Pangan.

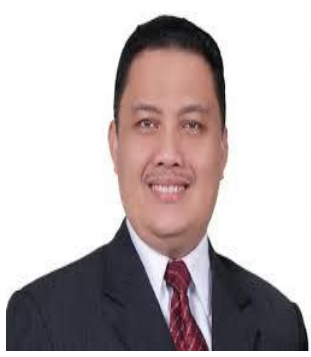

Prof. Dr. Ir. Hapzi Ali, MM, CMA, lahir di desa terpencil

Rantau

Embacang Kabupaten Bungo Provinsi Jambi tanggal 1 Desember 1966.

SD, SMP dan SMA dilalui dan diselesaikan di Bungo, gelar B.Sc (D3) diperoleh dari AMIK (UPI) YPTK Padang (1989), gelar Insinyur (Ir) diperoleh dari STMIK (UPI) YPTK Padang (1992), pernah kuliah pada Program Magister Computer Science di Universiti Technology Malaysia (UTM) tahun 19951996 dan mendapat sertifikat kompetensi dalam bidang Computer Science (Free-MSc), selanjutnya memperoleh gelar Magister Managemen (MM) dari Program Pascasarjana Uhamka Jakarta (2002), Doktor (Dr) di peroleh dari Program Doktor Manajemen Bisnis (DMB) Universitas Padjadjaran (UNPAD) Bandung (2010), gelar Guru Besar atau Professor (Prof) diperoleh tahun 2011 dari Kemendikti RI, dan terakhir pada tahun 2015 mendapat anugerah gelar kompetensi Certificate Marketing Analys (CMA) dari American Academy Project Management (AAPM). Karir Dosen dimulai sebagai asisten dosen di Laboratorium komputer UPI-YPTK padang semenjak semester III (1998), setelah selesai S1 (2003) langsung diangkat menjadi dosen tetap pada STMIK-UPI padang (20022003), diangkat menjadi dosen kopertis Wilayah X Sumbar-Riau-Jambi-kepri dpk. STMIK-UPI padang (2003-2006) dan tahun 2006-2016 dpk Universitas Batang Hari Jambi. Mulai 2016 sebagai Dosen kopertis Wilayah III dpk Universitas Mercubuana Jakarta. Aktif melakukan riset dan publikasi artikel pada jurnal ilmiah bereputasi seperti terindex scopus,Copernicus dan index lain. Aktif juga menjadi narasumber baik skala Internasional, Nasional dan Regional.

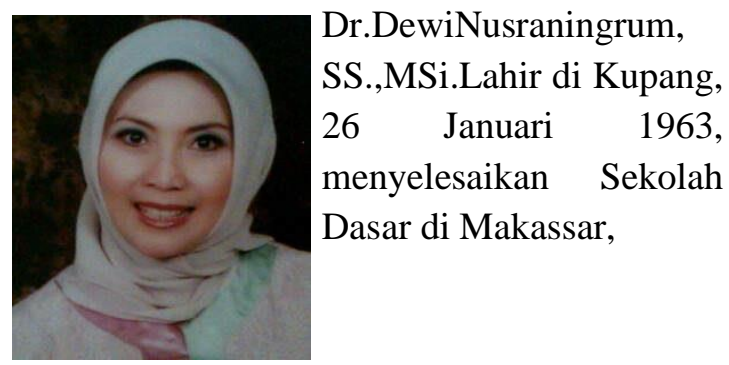

Sekolah Menengah Pertama di Banyuwangi dan Sekolah Menengah Atas di Surabaya. Mendapatkan gelar Sarjana Muda dari ABA di Jakarta tahun 1986 dan lulus Sarjana dari STIA-Lembaga Administrasi Negara tahun 1998. Saat ini beliau adalah Associate Professor dengan bidang keahlian Manajemen dan Komisaris Utama PT Mudah Sarana Energi. Memperoleh gelar Doktor dari Universitas Negeri Jakarta tahun 2004, Master of Science dalam bidang Kebijakan Bisnis dari Universitas Indonesia tahun 2000. Aktif mengajar sejak tahun 1989 hingga sekarang dalam bidang Manajemen, Manajemen Transportasi, Manajemen Operasi, Manajemen Pemasaran, Manajemen Sumber Daya Manusia dan Human Factors. 


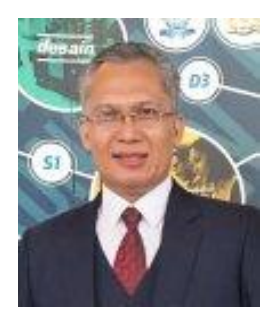

Dr. Mochammad Mukti

Ali, ST., MM. Professor

dibidang Strategi

Manajemen dan

Pemasaran pada Global

Academy of Finance \&

Management (GAFM)

merupakan

lulusan Doktor di bidang Manajemen dan Bisnis dari Institut Pertanian Bogor (IPB) ini, selain pernah menjabat sebagai Staff Ahli Direksi salah satu BUMD di Surabaya dan Direktur pemasaran Universitas Mercu Buana Jakarta, sampai saat ini menjabat sebagai Advisor dan Direktur Pengembangan YBBAI, Direktur Operasional PT. Bressindo Media Edukasi, Angota pengurus Sekolah SMP dan SMA Labschool Cirendeu dibawah Yayasan Pendidikan EDUKARSA Presiden Direktur sekaligus pemilik PT. Global Teknik Engineering dan Marketing \& Management Academy (MMA Center) serta sebagai pengajar tetap S2 dan S3 di Sekolah Bisnis IPB, Program Pascasarjana dan beberapa Universitas lainnya. 
